\title{
Lactobacillus floricola sp. nov., lactic acid bacteria isolated from mountain flowers
}

\author{
Correspondence \\ Shinji Kawasaki \\ kawashin@nodai.ac.jp
}

\author{
Shinji Kawasaki, ${ }^{1}$ Kana Kurosawa, ${ }^{1}$ Madoka Miyazaki, ${ }^{1}$ Chisato Yagi, ${ }^{1}$ \\ Yoritaka Kitajima, ${ }^{1}$ Shigeta Tanaka, ${ }^{1}$ Tomohiro Irisawa, ${ }^{2}$ Sanae Okada, ${ }^{3}$ \\ Mitsuo Sakamoto, ${ }^{4}$ Moriya Ohkuma ${ }^{4}$ and Youichi Niimura ${ }^{1}$ \\ ${ }^{1}$ Department of Bioscience, Tokyo University of Agriculture, 1-1-1 Sakuragaoka, Setagaya, \\ Tokyo 156-8502, Japan \\ ${ }^{2}$ Department of Applied Biology and Chemistry, Tokyo University of Agriculture, 1-1-1 \\ Sakuragaoka, Setagaya, Tokyo 156-8502, Japan \\ ${ }^{3} \mathrm{NODAl}$ Culture Collection Center, Tokyo University of Agriculture, 1-1-1 Sakuragaoka, \\ Setagaya, Tokyo 156-8502, Japan \\ ${ }^{4}$ Microbe Division/Japan Collection of Microorganisms, RIKEN BioResource Center, Wako, \\ Saitama 351-0198, Japan
}

\begin{abstract}
Five strains (Ryu1-2 ${ }^{\top}$, Gon2-9, Ryu4-3, Nog8-1 and Aza1-1) of lactic acid bacteria were isolated from flowers in mountainous areas in Japan, Oze National Park, lizuna mountain and the Nikko area. The five isolates were found to share almost identical (99.6-100\% similar) 16S rRNA gene sequences and were therefore deemed to belong to the same species. These isolates exhibited low levels of $16 \mathrm{~S}$ rRNA gene sequence similarity to known lactic acid bacteria; the closest recognized relatives to strain Ryu $1-2^{\top}$ were the type strains of Lactobacillus hilgardii (92.8\% similarity), Lactobacillus kefiri (92.7\%), Lactobacillus composti (92.6\%) and Lactobacillus buchneri (92.4\%). Comparative analyses of rpoA and pheS gene sequences demonstrated that the novel isolates did not show significant relationships to other Lactobacillus species. The strains were Gram-stain-positive, catalase-negative and homofermentative. The isolates utilized a narrow range of carbohydrates as sources of carbon and energy, including glucose and fructose. On the basis of phenotypic characteristics and phylogenetic data, these isolates represent a novel species of the genus Lactobacillus, for which the name Lactobacillus floricola sp. nov. is proposed. The type strain is Ryu1-2 $2^{\top}\left(=\mathrm{NRIC} 0774^{\top}=\mathrm{JCM} 16512^{\top}=\mathrm{DSM} 23037^{\top}\right)$.
\end{abstract}

Lactobacillus strains have been isolated from several plant sources such as fruit, grass, leaves, tree sap, flowers, fermented vegetables and fermented beverages such as wine, malt whisky, shochu and beer (summarized by Hammes \& Hertel, 2009; Orla-Jensen, 1919; Douglas \& Cruess, 1936; Keddie, 1959; Carr \& Davies, 1970; Wibowo et al., 1985; Edwards et al., 1998; Bohak et al., 1998; Simpson et al., 2001; Endo \& Okada, 2007; Endo et al., 2009; Michaylova et al., 2007; Irisawa \& Okada, 2009). In the 1960s, Mundt and colleagues reported the distribution

Abbreviation: $L A B$, lactic acid bacteria.

The GenBank/EMBL/DDBJ accession numbers for the $16 \mathrm{~S}$ rRNA gene sequences of strains Ryu 1-2 ${ }^{\top}$, Gon2-9, Ryu4-3, Nog8-1 and Aza1-1 are AB523780-AB523784, respectively; those for the partial rpoA gene sequences of Ryu1-2 ${ }^{\top}$ and L. composti DSM $18527^{\top}$ are AB568092 and $A B 568093$, and those for the partial pheS gene sequences of Ryu $1-2^{\top}$ and L. composti DSM $18527^{\top}$ are AB568094 and AB568095.

Three supplementary figures are available with the online version of this paper. of lactic acid bacteria (LAB) in flowers found in a national park in the United States (Mundt, 1963; Mundt et al., 1967). During our studies on the distribution of anaerobes in flowers, we have isolated strains of a novel Lactobacillus species from several flower samples found in mountainous areas of national parks in Japan.

Flowers were collected from mountainous areas (over $1000 \mathrm{~m}$ elevation) in Japan in the years 2006-2009. We also collected flowers from Oze National Park in the years 2008-2009. Flower samples were collected using autoclaved forceps, and transferred immediately to sterile tubes. Bacteria were cultivated at $20-30{ }^{\circ} \mathrm{C}$ under anaerobic conditions on MRS agar (Difco), containing $5.0 \mathrm{~g}$ calcium carbonate and $15 \mathrm{~g}$ agar $\mathrm{l}^{-1}$. After isolation, the strains were maintained in MRS broth. We isolated five strains (Ryu1-2 ${ }^{\mathrm{T}}$, Gon2-9, Ryu4-3, Nog8-1 and Aza1-1) from different flower sources found in mountainous locations in Japan. The origins of the isolates are shown in Supplementary Fig. S1, available in IJSEM Online. A large 
number of colonies $\left(10^{4}-10^{8}\right.$ colonies per single flower) were obtained, and the $16 \mathrm{~S}$ rRNA gene sequences of randomly selected colonies suggested that these isolates represent the most abundant species in each flower (unpublished data).

Morphological, physiological and biochemical characteristics were determined according to the methods of Okada et al. (1992), Holdeman et al. (1977) and Gerhardt et al. (1981). Lactobacillus buchneri NRIC $1040^{\mathrm{T}}$, L. composti DSM $18527^{\mathrm{T}}$, L. hilgardii NRIC $1060^{\mathrm{T}}$, L. kefiri NRIC $1693^{\mathrm{T}}$ and L. salivarius NRIC $0739^{\mathrm{T}}$ were used as experimental reference strains in this study. Carbohydrate fermentation tests were conducted in modified MRS broth containing $0.5 \%(\mathrm{w} / \mathrm{v})$ of various carbohydrates. Acid production from carbohydrates was also tested by using the API 50CHL system (bioMérieux) in triplicate according to the manufacturer's instructions. DNA $\mathrm{G}+\mathrm{C}$ contents were determined according to Mesbah $e t$ al. (1989). Sequences of the 16S rRNA genes of the isolates were determined using the primers 27F (5'-GAGTTTGATCCTGGCTCAG-3'; Escherichia coli positions 8-27) and 1525R (5'-AGAAAGGAGGTGATCCAGCC-3'; E. coli positions 1525-1545) (Lane et al., 1985). The rpoA and pheS gene sequences for strain Ryul- $2^{\mathrm{T}}$ and L. composti DSM $18527^{\mathrm{T}}$ were amplified by PCR with degenerate primers rpoA21F (5'-ATGATYGARTTTGAAAAACC-3') and rpoA-23R ( $5^{\prime}$-ACHGTRTTRATDCCDGCRCG- $\left.3^{\prime}\right)$ and pheS-21F (5'CAYCCNGCHCGYGAYATGC-3') and pheS-23-R (5'-GGRTGRACCATVCCNGCHCC-3'), respectively (Naser et al., 2005; Chao et al., 2010).

The closest relatives of the isolates were determined by performing a search against public databases, and the sequences of the most closely related species were retrieved from the NCBI database. Multiple alignments of the sequences were carried out using the program CLUSTAL_X, version 2.0 (Thompson et al., 1997). Distance matrices for the aligned sequences were calculated using the twoparameter method of Kimura (1980). The neighbourjoining method (Saitou \& Nei, 1987) was used to construct a phylogenetic tree. The robustness of individual branches was estimated by bootstrapping with 1000 replicates (Felsenstein, 1985). Phylogenetic trees were also constructed using the maximum-likelihood (Cavalli-Sforza \& Edwards, 1967) and maximum-parsimony (Kluge \& Farris, 1969) methods by using PHYLIP version 3.65 (Felsenstein, 2005). The 16S rRNA gene sequences of the isolates were compared, and the sequence of Ryu $1-2^{\mathrm{T}}$ was used to search for sequence similarities within the database. Sequences of approx. $1500 \mathrm{bp}$ of the 16S rRNA gene (approx. $400 \mathrm{bp}$ for rpoA and $350 \mathrm{bp}$ for pheS) were used to construct phylogenetic trees. The sequence of Ryu $1-2^{\mathrm{T}}$ showed quite low sequence similarity to known species of LAB: all similarities were less than $93 \%$, and the closest known relatives were the type strains of $L$. hilgardii $(92.8 \%)$, L. kefiri $(92.7 \%)$, L. composti $(92.6 \%)$ and L. buchneri $(92.4 \%)$. The isolates clustered most closely with L. composti (Endo \& Okada, 2007) using the neighbourjoining and maximum-parsimony methods (Fig. 1 and
Supplementary Fig. S2a) and with $L$. salivarius (Rogosa et al., 1953) using the maximum-likelihood method (Supplementary Fig. S2b). These sequence similarities are significantly lower than those recommended for species differentiation (99\%; Stackebrandt \& Ebers, 2006). Therefore, DNA-DNA hybridization between the isolates and known $\mathrm{LAB}$ was not carried out. The similarities among the $r p o A$ and pheS gene sequences of the proposed type strain and the closest neighbouring species were $65-70$ and $57-71 \%$, respectively. On the basis of neighbourjoining analysis of the rpoA and pheS gene sequences (Supplementary Fig. S3), the novel strain did not belong to any known species. Similar topologies were obtained by the minimum evolution and maximum-parsimony methods (not shown). The DNA G $+\mathrm{C}$ content of the strain Ryu1$2^{\mathrm{T}}$ was $48 \mathrm{~mol} \%$.

The 16S rRNA gene sequence of strain Ryul $-2^{\mathrm{T}}$ was $100 \%$ identical to that of strain Gon2-9 and exhibited high sequence identity to those of strains Ryu4-3 (one base difference), Nog8-1 (99.6\%) and Azal-1 (99.6\%). The sequences of Nog8-1 and Aza1-1 were identical. To attempt to differentiate these strains, strains Ryu1-2 ${ }^{\mathrm{T}}$, Gon2-9, Ryu4-3, Nog8-1 and Aza1-1 were analysed by randomly amplified polymorphic DNA (RAPD)-PCR according to the method of Akopyanz et al. (1992) using two primers (primer-1, 5'-GAGGACAAAG; primer-2, 5'-GGCATCGGTT) (Morotomi et al., 2002). RAPD-PCR demonstrated genotypic differences between the strains (Fig. 2). We

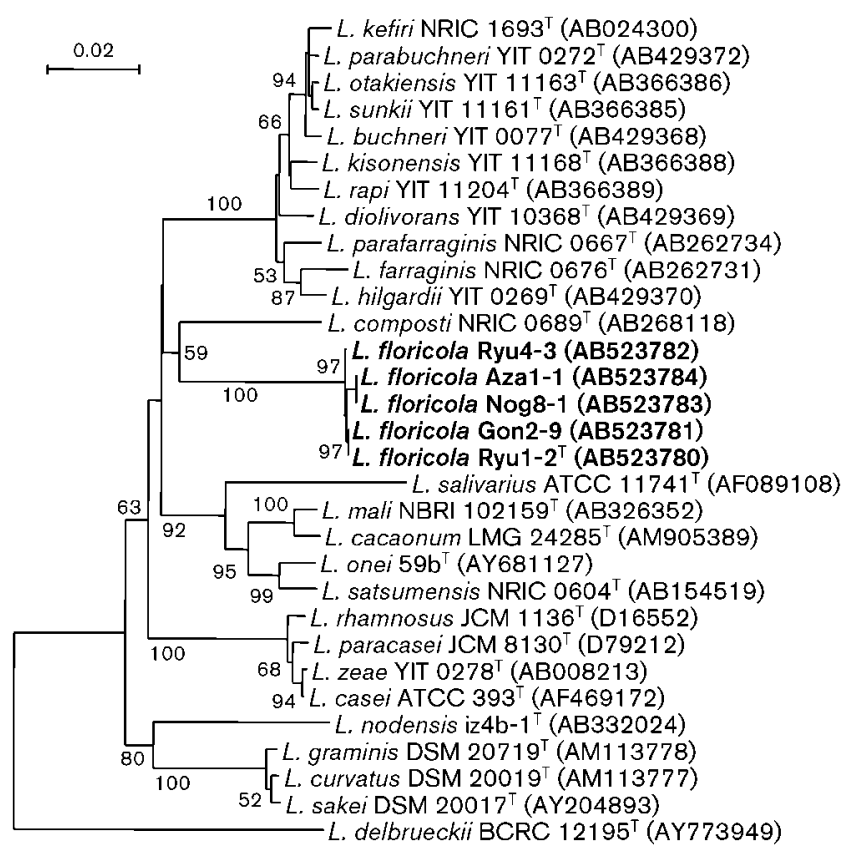

Fig. 1. Phylogenetic tree showing the relationship between the novel strains from mountain flowers and related species. The tree was constructed using the neighbour-joining method based on $16 \mathrm{~S}$ rRNA gene sequences. Bootstrap values above $50 \%$ are given at branching points. Bar, evolutionary distance $\left(K_{\text {nuc }}\right)$ of 0.02 . 
concluded that the isolated strains are widely distributed in mountain flowers but are not specific to a particular area.

Morphological, physiological and biochemical characteristics of the isolates were determined using MRS broth as a basal medium. Detailed characteristics are given in the species description. The biochemical characteristics were compared with those of the phylogenetic relatives L. hilgardii, L. composti, L. kefiri, L. salivarius and L. buchneri (Table 1). The isolates were homofermentative $\mathrm{LAB}$ and produced L-lactic acid from D-glucose, as determined by using $\mathrm{L}^{-}$and D-lactate dehydrogenase (Sigma) (Latorre-Guzman et al., 1977). This finding was also confirmed by performing HPLC analysis with a separation column for optical isomers (CRS10W column; Mitsubishi Chemical) (Otsuka et al., 1994; Manome et al., 1998). Production of lactic acid but not ethanol from glucose was detected by using gas chromatography. The strain grew well at 20 and $30{ }^{\circ} \mathrm{C}$ (optimum), slowly at $15{ }^{\circ} \mathrm{C}$ and not at all at 10 or $37^{\circ} \mathrm{C}$. The strain produced acid from a narrow range of carbohydrates such as glucose and fructose. Growth by utilization of glucose was relatively better than that with fructose, as determined by measuring maximum growth by monitoring the $\mathrm{OD}_{660}$ for $24-48 \mathrm{~h}$ at $30^{\circ} \mathrm{C}$.

On the basis of phenotypic characteristics and phylogenetic data, the isolates represent a novel species, for which the name Lactobacillus floricola sp. nov. is proposed.

\section{Description of Lactobacillus floricola sp. nov.}

Lactobacillus floricola (flo.ri'co.la. L. n. flos -oris a flower; L. suff. - cola derived from L. n. incola a dweller; N.L. n. floricola flower-dweller).

Cells are Gram-stain-positive at the early stages of growth but are not clearly stained at the late exponential to stationary phase. They are non-spore-forming, non-motile rods, $0.5 \times 2-4 \mu \mathrm{m}$, and occur singly, in pairs or in short chains. Catalase-negative. Colonies develop well on MRS

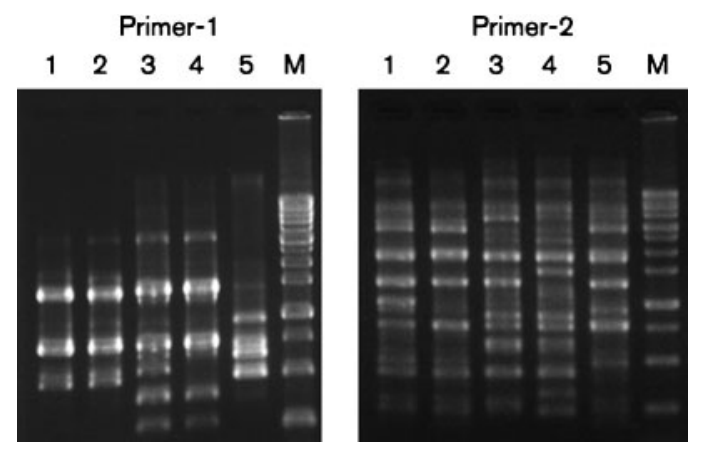

Fig. 2. RAPD-PCR fingerprints of strains of Lactobacillus floricola sp. nov. Lanes: 1, Ryu1-2' ; 2, Ryu4-3; 3, Nog8-1; 4, Aza1-1; 5, Gon2-9; $\mathrm{M}$, size marker (1 kb ladder; GeNECRAFT). Primer-1 and primer-2 were used (see text).
Table 1. Differential characteristics of strain Ryu $1-2^{\top}$ and closely related lactobacilli

Strains: 1 , Ryu1-2 ${ }^{\mathrm{T}} ; 2$, L. composti DSM $18527^{\mathrm{T}} ; 3$, L. hilgardii NRIC $1060^{\mathrm{T}}$; 4, L. kefiri NRIC $1693^{\mathrm{T}}$; 5, L. salivarius NRIC $0739^{\mathrm{T}}$; 6, L. buchneri NRIC $1040^{\mathrm{T}}$. Data were obtained in this study. + , Positive; w, weakly positive; -, negative. Carbohydrate fermentation tests were confirmed by using API 50CHL; strain Ryu 1-2 produced acid from D-glucose and D-fructose of the 49 carbohydrates in API 50CHL. None of the strains fermented cellobiose, and all strains fermented fructose.

\begin{tabular}{|lcccccc|}
\hline Characteristic & $\mathbf{1}$ & $\mathbf{2}$ & $\mathbf{3}$ & $\mathbf{4}$ & $\mathbf{5}$ & $\mathbf{6}$ \\
\hline Lactic acid isomer(s) & $\mathrm{L}$ & $\mathrm{DL}$ & $\mathrm{DL}$ & $\mathrm{DL}$ & $\mathrm{L}$ & $\mathrm{DL}$ \\
$\begin{array}{l}\text { Fermentative } \\
\text { behaviour }\end{array}$ & Ho & $\mathrm{He}$ & $\mathrm{He}$ & $\mathrm{He}$ & $\mathrm{Ho}$ & $\mathrm{He}$ \\
Fermentation of: & & & & & & \\
$\quad$ Arabinose & - & + & - & + & - & + \\
Galactose & - & + & - & + & + & + \\
Lactose & - & - & - & + & + & - \\
Maltose & - & + & + & + & + & + \\
Mannitol & - & + & - & - & + & - \\
Mannose & - & + & - & - & + & - \\
Melezitose & - & + & - & - & - & + \\
Rhamnose & - & w & - & - & W & - \\
Ribose & - & - & + & w & - & + \\
Salicin & - & w & - & - & - & - \\
Sorbitol & - & + & - & - & + & - \\
Trehalose & - & + & - & w & + & - \\
\end{tabular}

${ }^{\star}$ Ho, Homofermentative; He, heterofermentative.

agar plates under both anaerobic and aerobic (air) conditions. Colonies on MRS agar are yellowish-white, smooth and approx. 1-2 $\mathrm{mm}$ in diameter after incubation for 2 days at $30{ }^{\circ} \mathrm{C}$. Homofermentative. No gas is produced from glucose. L-Lactic acid is produced as the end product from glucose. Nitrate is not reduced. Acid is produced from D-glucose and D-fructose; weak production is observed from starch. No acid is produced from D-galactose, D-mannose, D-arabinose, D-xylose, maltose, melibiose, sucrose, trehalose, melezitose, D-mannitol, D-sorbitol, D-ribose, cellobiose, lactose, raffinose, D-gluconate, L-rhamnose or salicin. Utilization of glucose is relatively better than that of fructose. Cells grow at $20-30{ }^{\circ} \mathrm{C}$ and grow slowly at $15{ }^{\circ} \mathrm{C}$, but not at 10 or $37^{\circ} \mathrm{C}$. Cells grow at $30^{\circ} \mathrm{C}$ in the presence of $5.5 \%(\mathrm{w} / \mathrm{v}) \mathrm{NaCl}$ but not $6.5 \%(\mathrm{w} / \mathrm{v})$. Cells do not contain meso-diaminopimelic acid in their peptidoglycan. The DNA $\mathrm{G}+\mathrm{C}$ content of the type strain is $48 \mathrm{~mol} \%$.

The type strain is Ryul- $2^{\mathrm{T}}\left(=\mathrm{NRIC} 0774^{\mathrm{T}}=\mathrm{JCM} 16512^{\mathrm{T}}\right.$ $=$ DSM $23037^{\mathrm{T}}$ ), isolated from a flower of Caltha palustris (Japanese common name ryukinka) in the Oze National Park in June 2008. Four additional strains, Aza1-1 (=NRIC $0775=$ JCM 16513), Nog8-1 (=NRIC $0776=$ JCM 16514), Gon2-9 (=NRIC $0777=$ JCM 16515) and Ryu4-3 (=NRIC $0778=$ JCM 16516) are included in this species (details in Supplementary Fig. S1). 


\section{Acknowledgements}

We are grateful to Mr Michio Fujita and Ms Kana Hayamidzu, Japanese Ministry of Environment, for helpful discussions and sample collection at Oze National Park. We are also grateful to the Agency of Cultural Affairs and the Tokyo Electric Power Company for helpful advice and assistance with sample collection at Oze National Park.

\section{References}

Akopyanz, N., Bukanov, N. O., Westblom, T. U., Kresovich, S. \& Berg, D. E. (1992). DNA diversity among clinical isolates of Helicobacter pylori detected by PCR-based RAPD fingerprinting. Nucleic Acids Res 20, 5137-5142.

Bohak, I., Back, W., Richter, L., Ehrmann, M., Ludwig, W. \& Schleifer, K. H. (1998). Lactobacillus amylolyticus sp. nov., isolated from beer malt and beer wort. Syst Appl Microbiol 21, 360-364.

Carr, J. G. \& Davies, P. A. (1970). Homofermentative lactobacilli of ciders including Lactobacillus mali nov. spec. J Appl Bacteriol 33, 768-774.

Cavalli-Sforza, L. L. \& Edwards, A. W. F. (1967). Phylogenetic analysis. Models and estimation procedures. Am J Hum Genet 19, 233-257.

Chao, S. H., Sasamoto, M., Kudo, Y., Fujimoto, J., Tsai, Y. C. \& Watanabe, K. (2010). Lactobacillus odoratitofui sp. nov., isolated from stinky tofu brine. Int J Syst Evol Microbiol 60, 2903-2907.

Douglas, H. C. \& Cruess, W. V. (1936). A Lactobacillus from California wine: Lactobacillus hilgardii. Food Res 1, 113-119.

Edwards, C. G., Haag, K. M., Collins, M. D., Hutson, R. A. \& Huang, Y. C. (1998). Lactobacillus kunkeei sp. nov.: a spoilage organism associated with grape juice fermentations. J Appl Microbiol 84, 698-702.

Endo, A. \& Okada, S. (2007). Lactobacillus composti sp. nov., a lactic acid bacterium isolated from a compost of distilled shochu residue. Int J Syst Evol Microbiol 57, 870-872.

Endo, A., Futagawa-Endo, Y. \& Dicks, L. M. T. (2009). Isolation and characterization of fructophilic lactic acid bacteria from fructose-rich niches. Syst Appl Microbiol 32, 593-600.

Felsenstein, J. (1985). Confidence limits on phylogenies: an approach using the bootstrap. Evolution 39, 783-791.

Felsenstein, J. (2005). PHYLIP (phylogeny inference package), version 3.6. Distributed by the author. Department of Genome Sciences, University of Washington, Seattle, USA.

Gerhardt, P., Murray, R. G. E., Costilow, R. N., Nester, E. W., Wood, W. A., Krieg, N. R. \& Phillips, G. B. (1981). Manual of Methods for General Bacteriology. Washington, DC: American Society for Microbiology.

Hammes, W. P. \& Hertel, C. (2009). Genus I. Lactobacillus Beijerinck $1901,212^{\mathrm{AL}}$. In Bergey's Manual of Systematic Bacteriology, 2nd edn, vol. 3, pp. 465-513. Edited by P. De Vos, G. Garrity, D. Jones, N. R. Krieg, W. Ludwig, F. A. Rainey, K. H. Schleifer \& W. B. Whitman. New York: Springer.

Holdeman, L. V., Cato, E. P. \& Moore, W. E. C. (1977). Anaerobe Laboratory Manual. Blacksburg, VA: Virginia Polytechnic Institute and State University.

Irisawa, T. \& Okada, S. (2009). Lactobacillus sucicola sp. nov., a motile lactic acid bacterium isolated from oak tree (Quercus sp.) sap. Int J Syst Evol Microbiol 59, 2662-2665.

Keddie, R. M. (1959). The properties and classification of lactobacilli isolated from grass and silage. J Appl Bacteriol 22, 402-416.

Kimura, M. (1980). A simple method for estimating evolutionary rates of base substitutions through comparative studies of nucleotide sequences. J Mol Evol 16, 111-120.
Kluge, A. G. \& Farris, J. S. (1969). Quantitative phyletics and the evolution of the anurans. Syst Zool 18, 1-32.

Lane, D. J., Pace, B., Olsen, G. J., Stahl, D. A., Sogin, M. L. \& Pace, N. R. (1985). Rapid determination of $16 \mathrm{~S}$ ribosomal RNA sequences for phylogenetic analyses. Proc Natl Acad Sci U S A 82, 6955-6959.

Latorre-Guzman, B. A., Kado, C. I. \& Kunkee, R. E. (1977). Lactobacillus hordniae, a new species from the leafhopper (Hordnia circellata). Int J Syst Bacteriol 27, 362-370.

Manome, A., Okada, S., Uchimura, T. \& Komagata, K. (1998). The ratio of $\mathrm{L}$-form to $\mathrm{D}$-form of lactic acid as a criteria for the identification of lactic acid bacteria. J Gen Appl Microbiol 44, 371-374.

Mesbah, M., Premachandran, U. \& Whitman, W. B. (1989). Precise measurement of the $\mathrm{G}+\mathrm{C}$ content of deoxyribonucleic acid by highperformance liquid chromatography. Int J Syst Bacteriol 39, 159-167.

Michaylova, M., Minkova, S., Kimura, K., Sasaki, T. \& Isawa, K. (2007). Isolation and characterization of Lactobacillus delbrueckii ssp. bulgaricus and Streptococcus thermophilus from plants in Bulgaria. FEMS Microbiol Lett 269, 160-169.

Morotomi, M., Yuki, N., Kado, Y., Kushiro, A., Shimazaki, T., Watanabe, K. \& Yuyama, T. (2002). Lactobacillus equi sp. nov., a predominant intestinal Lactobacillus species of the horse isolated from faeces of healthy horses. Int J Syst Evol Microbiol 52, 211-214.

Mundt, J. O. (1963). Occurrence of enterococci on plants in a wild environment. Appl Microbiol 11, 141-144.

Mundt, J. O., Graham, W. F. \& McCarty, I. E. (1967). Spherical lactic acid-producing bacteria of southern-grown raw and processed vegetables. Appl Microbiol 15, 1303-1308.

Naser, S. M., Thompson, F. L., Hoste, B., Gevers, D., Dawyndt, P., Vancanneyt, M. \& Swings, J. (2005). Application of multilocus sequence analysis (MLSA) for rapid identification of Enterococcus species based on rpoA and pheS genes. Microbiology 151, 2141-2150.

Okada, S., Uchimura, T. \& Kozaki, M. (1992). Laboratory Manual for Lactic Acid Bacteria. Tokyo: Asakura-shoten.

Orla-Jensen, S. (1919). The Lactic Acid Bacteria. Copenhagen: Høst and Son.

Otsuka, M., Okada, S., Uchimura, T. \& Komagata, K. (1994). A simple method for the determination of stereoisomers of lactic acid by HPLC using an enantiomeric resolution column, and its application to identification of lactic acid bacteria. Seibutsu-kogaku Kaishi 72, 81-86 (in Japanese).

Rogosa, M., Wiseman, R. F., Mitchell, J. A., Disraely, M. N. \& Beaman, A. J. (1953). Species differentiation of oral lactobacilli from man including description of Lactobacillus salivarius nov. spec. and Lactobacillus cellobiosus nov. spec. J Bacteriol 65, 681-699.

Saitou, N. \& Nei, M. (1987). The neighbor-joining method: a new method for reconstructing phylogenetic trees. Mol Biol Evol 4, 406-425.

Simpson, K. L., Pettersson, B. \& Priest, F. G. (2001). Characterization of lactobacilli from Scotch malt whisky distilleries and description of Lactobacillus ferintoshensis sp. nov., a new species isolated from malt whisky fermentations. Microbiology 147, 1007-1016.

Stackebrandt, E. \& Ebers, J. (2006). Taxonomic parameters revised: tarnished gold standards. Microbiol Today 33, 152-155.

Thompson, J. D., Gibson, T. J., Plewniak, F., Jeanmougin, F. \& Higgins, D. G. (1997). The CLUSTAL_X windows interface: flexible strategies for multiple sequence alignment aided by quality analysis tools. Nucleic Acids Res 25, 4876-4882.

Wibowo, D., Eschenbruch, R., Davis, C. R., Fleet, G. H. \& Lee, T. H. (1985). Occurrence and growth of lactic acid bacteria in wine: a review. Am J Enol Vitic 36, 302-313. 